\title{
What's the matter with Benjamin O. Flower?
}

Populism, antimonopoly politics and the "paranoid style" at the turn of the century

Jean-Louis Marin-Lamellet

\section{(2) OpenEdition}

\section{Journals}

Electronic version

URL: https://journals.openedition.org/ejas/10086

DOI: 10.4000/ejas.10086

ISSN: 1991-9336

Publisher

European Association for American Studies

\section{Electronic reference}

Jean-Louis Marin-Lamellet, "What's the matter with Benjamin O. Flower?", European journal of American studies [Online], 8-1 | 2013, Online since 06 September 2013, connection on 08 July 2021. URL: http:// journals.openedition.org/ejas/10086 ; DOI: https://doi.org/10.4000/ejas.10086

This text was automatically generated on 8 July 2021.

Creative Commons License 


\section{What's the matter with Benjamin 0. Flower?}

Populism, antimonopoly politics and the "paranoid style" at the turn of the century

Jean-Louis Marin-Lamellet

1 As an editor of several magazines and a publisher, Boston reformer Benjamin Orange Flower (1858-1918, figure 1) publicized and advocated many Progressive and radical causes of his times: Populism, woman suffrage, direct legislation, public ownership of utilities, public works for the unemployed, railroad regulation and temperance to name but a few examples. ${ }^{1}$ In the 1910s, he denounced the "medical monopolies" that wanted to crush alternative medicine. At the end of his life, he also edited a widely-circulated anti-Catholic newspaper, The Menace. Flower exemplified "how men of this era thought in strange theoretical combinations" and opened the pages of his magazines to all the unorthodox ideas of his times, thus acquiring the reputation of a "radical crank." $\mathrm{He}$ believed that his editorial policy should illustrate the American spirit of freedom; the intense intellectual activity would then be conducive to reforms. ${ }^{3}$ 
Figure 1: Benjamin Orange Flower ${ }^{4}$

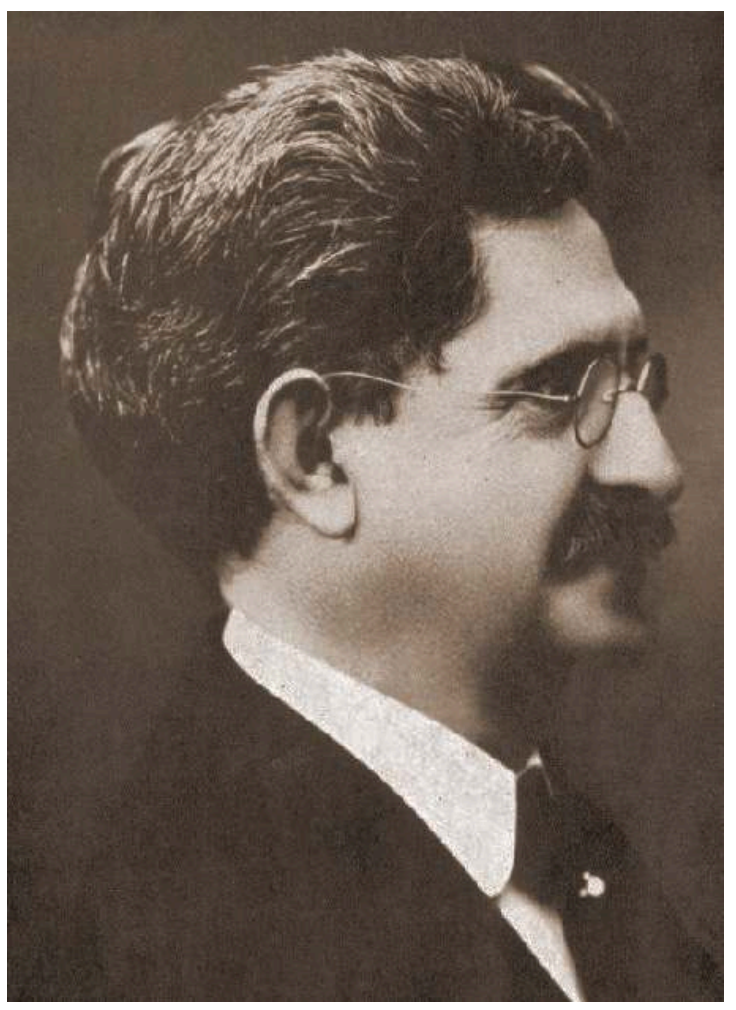

2 Flower fought all his crusades in the name of "the people." At the beginning of the 1890s, he purposed to give Populists the full and fair hearing that the partisan press denied them. ${ }^{5}$ The aim of this article is first to propose a reconstructive understanding of Populism, a Western and Southern phenomenon mainly, from the perspective of an Eastern and urban supporter and one of its main publicists (but not a Populist per se), and, therefore, to recapture the meaning of "Populism" as it was popularized at the time. Secondly, Flower was both a reformist journalist and, at the end of his life, an anti-Catholic fanatic. I will try and account for this ambiguous intellectual trajectory and expose the inadequacy of the rural/ urban and left/ right dichotomies to appreciate the "populist" phenomenon in general and Flower's evolution in particular. Instead, I argue that defining his "theoretical combinations" as "strange" reveals more about $20^{\text {th }}$ intellectual life than about reformers like Flower - his time can be best understood as the confrontation between the more radical antimonopoly strand of Progressivism he promoted and the managerial liberalism fostered by the more technocratic elements among Progressives, Populism being just one moment of this division within the camp of progress.

"What's the matter with Kansas?"6 That question, raised by William Allen White in his 1896 sarcastic diatribe against the Populists, is also relevant for Flower. How could such an idealistic, fearlessly progressive intellectual turn into, first, the enemy of federal health regulation in the 1910s, using the same arguments as today's Republicans against healthcare reforms, and, then, after 1915, into the editor of an anti-Catholic hate sheet? Is this drift towards conservatism and nativism really the fate of "populism"? His Progressive contemporaries and historians expressed dismay at this evolution. ${ }^{7}$ Flower's strange intellectual trajectory is also that of states like Kansas, where the radical spirit of Populism emerged, or Oklahoma, whose 1907 constitution 
was a "model of populist-progressivism"; both states are now seen as conservative strongholds. " "What's the Matter with Kansas?," still a topical question, led journalist Thomas Frank to claim that, at the end of the $20^{\text {th }}$ century, "conservatives won the heart of America by convincing poor Kansans to vote against their own economic interests in a vain effort to defend traditional cultural values against radical bicoastal elites." 9 Flower's case will help continue this discussion. It will also show how historical categories can be subjectivized and acted upon, thus offering an insight into an intellectual tradition, the antimonopoly strand of Progressivism, which has been neglected by historiography. Before turning to Flower's evolution however, let me offer a few elements to better understand "populism" - as a rhetorical tool, it has been not only vague and ahistorical, since the "people" could be understood in ethnic, class, or nationalistic terms, but also a loaded and contested term.

\section{What we talk about when we talk about "populism"}

4 Flower actively supported Populism. The Arena was the only Eastern magazine to support what he called "the agrarian uprising of the early nineties." Leaders of the movement - Tom Watson, James Weaver, Marion Butler, John Davis, Anne Diggs, Leonidas Polk, and Herman Taubeneck to name but a few - wrote 87 articles in its pages, mostly between 1892 and 1896 (figure 2). Flower wrote 40 laudatory editorials, published 13 Populist books and reprinted Populist articles in pamphlet form (figure 3). In 1896, Flower endorsed the Democratic and Populist candidate William Jennings Bryan, the "Trustee of the People," even if it allegedly cost him a cut in advertising. ${ }^{10}$ Populist leaders quoted The Arena in their campaigns; Farmers' Alliances and People's Parties subscribed to the magazine; even poor farmers read it - in short it was "the textbook of the Populist movement."11

Figure 2: number of articles about Populism in The Arena by year

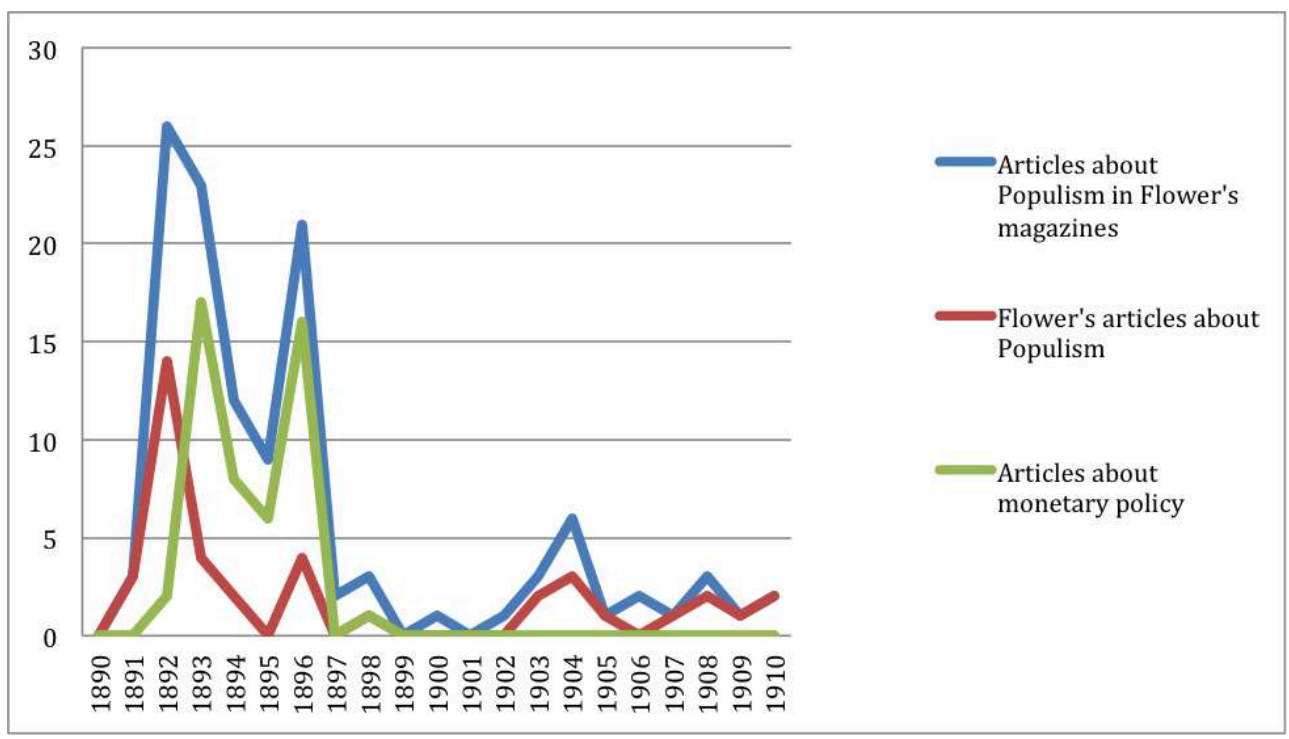



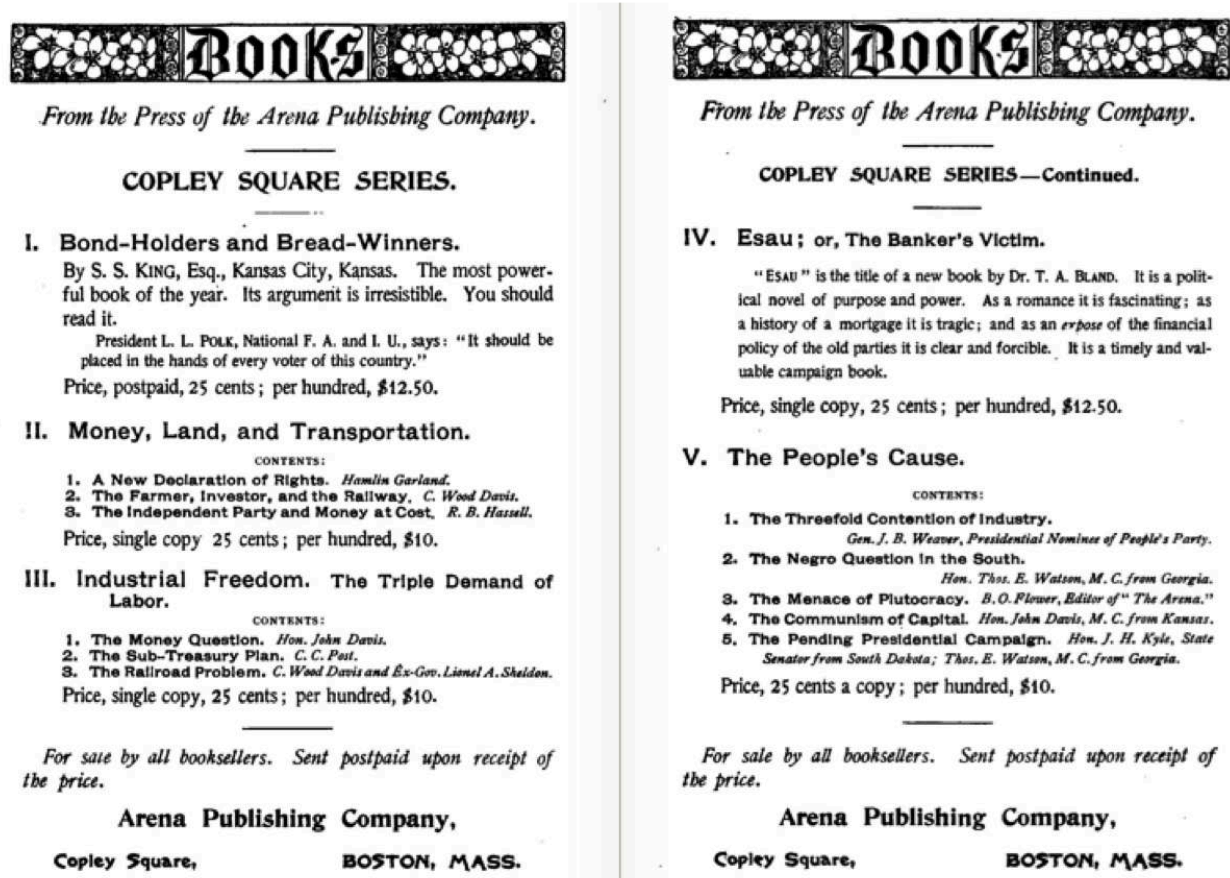

5 It is therefore worth noticing that, even though "Populism" as a term was first used in $1891,{ }^{12}$ it was surprisingly absent in Flower and his contributors' prose - in more than 20 years of monthlies and thousands of pages, it can be found only once in $1895 .{ }^{13}$ "Populist," on the other hand, was more common, in Flower's magazines and in the national conversation in general. ${ }^{14}$ The phrases that kept cropping up to refer to the agrarian revolt were the "People's Party" and "the people." All the articles published by Flower therefore foregrounded the citizens choosing a concrete political alternative, not the ideology. In the 1890s, "Populist" did not mean "demagogue" - it was a positive term reformers used to underline their determination to restore the will of the people in American politics. On the contrary, Flower branded corrupt politicians and the press at its beck and call as "glib-tongued 'demagogues" who were "subservient to the existing order." ${ }^{15}$ His opponents also did not use the word "Populist" derogatively; they disparaged agrarians as "fanatics, impractical dreamers" and above all "cranks."

6 A quantitative analysis of digitized books reveals that the use of "Populist" in print culture declined just before 1900, as the power of the People's Party declined in US politics. Then, there is an increase in the use of "Populist" and "Populism" again from 1915 onwards. At the time, it took on the derisive and stigmatizing meaning that came to be associated with the term in the $20^{\text {th }}$ century. By the 1920 s, it became common parlance with the meaning of "the views of the masses" in general. ${ }^{16}$ This shift corresponds to an increasing use of the term as a label to lump in all rural Americans and define them as backward-looking, irrational hayseeds. Under the pen of satirists like Mencken, rural Americans, with their "hoggish ways," are "barbarous," their refusal of the evolutionary theory serving as a symptom of cultural backwardness. In the hierarchy of "civilization," "the people" is reduced to animality and threatens to become an uncontrollable and violent crowd. The "people" becomes a "mob" and overpowers the "civilized minority." 17 
7 World War One seems to be a turning point. Reformers allied in the 1890s split. In 1915, Flower began to be involved in anti-Catholicism. Many Progressives and Socialists joined in the movement but Flower's involvement dismayed his radical friends..$^{18}$ In 1916, socialist activist and journalist Jack Reed followed Bryan on a trip to Florida and made fun of his cultural values even though they had the same reformist ideas. ${ }^{19}$ The same satirical mode, even cultural contempt, drew apart two former Populists, Bryan and Clarence Darrow, at the Scopes Trial and informed Hofstadter's seminal interpretation of Populism, "paranoid politics" and anti-intellectualism in the 1950s. ${ }^{20}$ The clash between two visions of Progressive politics thus became a symbol of the cultural gulf between "prairie Victorians" and "modernist heroes." ${ }^{21}$ Thus did the American Left split: populists like Bryan, radical in economic terms, remained more traditional culturally speaking than the sophisticated, secular urbanites represented by Reed, Darrow and Mencken. Cultural values seem to have trumped common reformist economic agendas. The Populist vision of democracy exalted $19^{\text {th }}$ century ideas of popular sovereignty and the nobility of "the people." It came into conflict with urban intellectuals' more patrician and technocratic vision that foregrounded the role of college-educated professionals. During the First World War, propaganda practices also turned "the people" into "public opinion" that could easily be manipulated. As a result, intellectuals - Mencken, Walter Lippmann and EdwardBernays to name a few influential examples - grew wary of the "ignorant" masses and began to understand progressivism in social control terms. Experts should "manufacture consent" and guide citizens on the path of reform. ${ }^{22}$

8 This shift solidified with the increasing tensions in the 1920s between urban and rural America over cultural issues like Prohibition, the Ku Klux Klan, evolution, and Al Smith's candidacy for the presidency in 1928 just as, demographically speaking, small town America declined and more people were lured to the big cities. ${ }^{23}$ These cultural wars of the 1920s saw the culmination of turn-of-the-century tensions between Catholics and Protestants over notably temperance and woman suffrage. Urban liberals framed the conflict in rural/ urban terms and associated each space to political values "the city" was then to be understood as the locus of progressive political activity and the American heartland as a stronghold of conservatism and, for some, even obscurantism. The rural/ urban dichotomy crystallized at the time and, afterwards, intellectuals tended to apply it retrospectively to the turn-of-the century. However, recent research refutes such a cleavage. ${ }^{24}$ Historiography mirrored demographical and cultural changes: we can find the same contempt, popularized by Mencken in the 1920s, in Hofstadter's classic image of Populists as backward-looking, nativist, Anglophobic, anti-Semitic and jingoistic (even though his dissertation advisor, Merle Curti, deplored his clear urban bias)or just lack of interest, as Elizabeth Sanders showed when she commented on the "strong urban labor bias" among social historians. ${ }^{25}$

\section{Populism as publicized by Flower}

\subsection{Populism, modernity and the rural/urban dichotomy}

For Flower however, the rural/ urban and progressive/ conservative dichotomies did not apply to understand the "agrarian uprising" of the 1890s. His seamless world of reformers included city and country, as shown by his own position as a Bostonian 
opening his magazine to Western and Southern protest voices. In "The Menace of Plutocracy," he portrayed the workers' struggle against Pinkertons during the Homestead strike as the same crusade as that of farmers. ${ }^{26} \mathrm{He}$ kept exposing the sham prosperity of the country, by depicting abject poverty as a systemic problem that was caused by "class legislation" and that straddled the "mortgaged-cursed frontier" and city tenements. Populist contributors to his magazines agreed. For instance, Flower promoted the work of Eva McDonald-Valesh, a Farmers' Alliance lecturer in Minnesota who fought for both women farmers and women workers in Minneapolis, St Paul and their surroundings. She wrote about agrarians' concerns but also about "the tenement house problem in New York." ${ }^{27}$ Not a single article described an opposition between rural and urban America: the image of Populism that emerges from Flower's magazines focuses on the national dimension of the fight. Always optimistic, Flower tended to turn a blind eye to the failures of unifying farmers and workers or blamed them on the divisive schemes of plutocrats. ${ }^{28}$

For Flower, Populists were on the side of progress. They represented a "large percentage of the reform element of society." ${ }^{29}$ In his memoir of the Progressive movement, Flower saw the "agrarian uprising" as one of the founding moments, along with the impact of Henry George and Edward Bellamy, of 25 years of progress. One in ten articles about Populism in his magazines hammered in the idea that it was in the van of progress (figure 4). One in ten consisted in the hagiography of Populist leaders, who were depicted as part of a historical vanguard: Tom Watson and James B. Weaver for instance were the leaders of "progressive forces that had definitely broken with the old order" (figure 4). For J.R. Buchanan, the purpose of Populism was to "emancipate the present from the barbarian ideas of the past." For Flower, this modernity was confirmed by the posthumous success of Populist measures. ${ }^{30}$

Figure 4: number of Populist articles in Flower's magazines according to topic

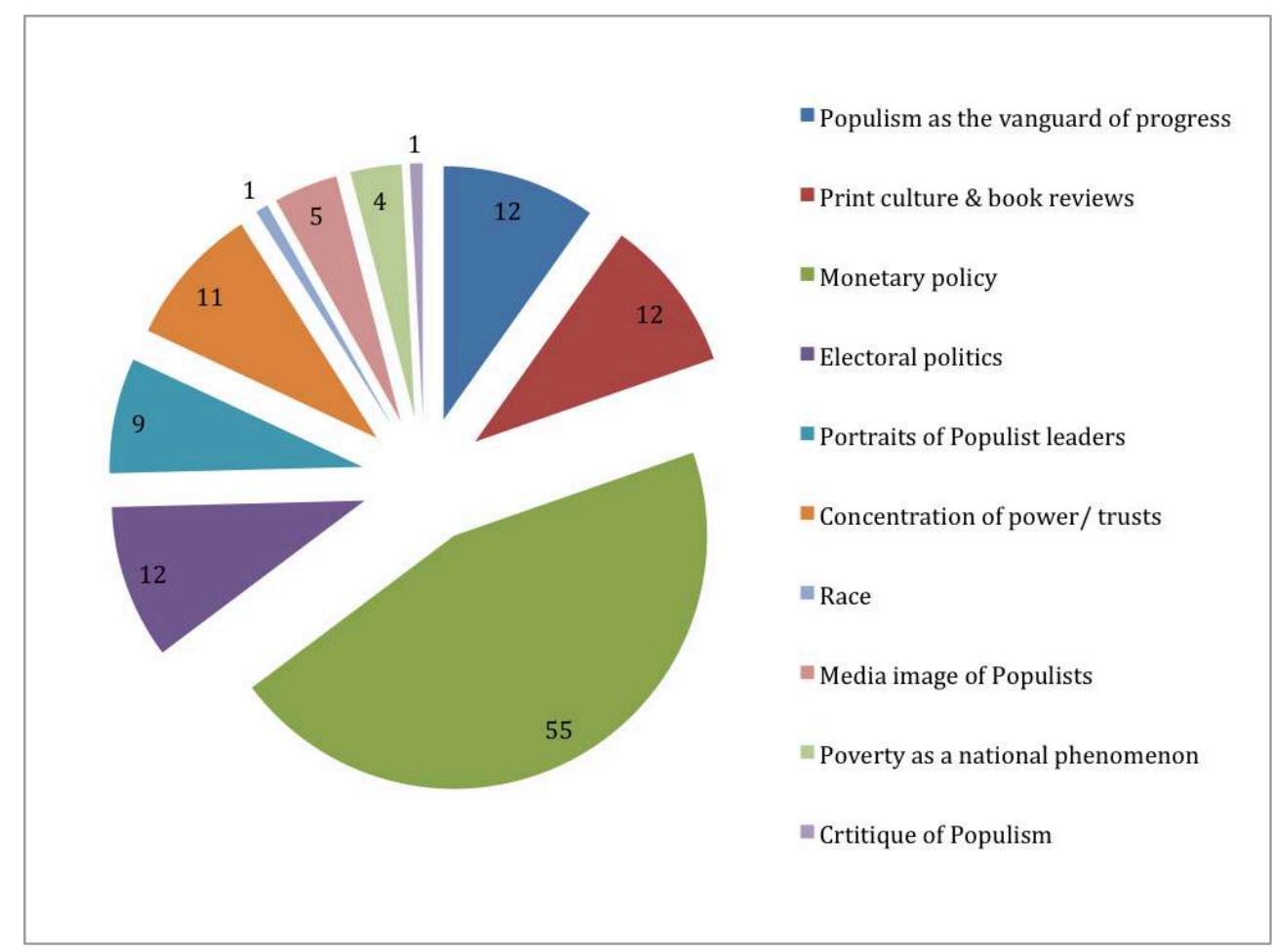

European journal of American studies, 8-1 | 2013 
11 Contrary to historians who later described Populism as the swansong of a pre-modern and republican past and Populists as tragic heroes (Lasch, Goodwyn, McMath) or as comic heroes (James Livingston) whose demise was necessary to modernize the country or, even contrary to Postel's revisionism that rejects the idea of Populism as a tradition-oriented movement, Flower and the writers he published saw no dichotomy between modernity and tradition. ${ }^{31}$ Science, modern technology and communication were accepted, not feared, and scientific management techniques were to be used to instill predictability in economic cycles. For instance, Flower saw Henry George's Single Tax as "scientific taxation." 32 Almost half of Populist articles in The Arena denounced an outdated conservative fiscal policy based on the gold standard and the tariff (figure 4). ${ }^{33}$ Government should take on regulatory powers and manage the volume of currency along scientific lines in order to keep pace with the demographical and commercial development of the country. Only an inflationary policy based on "free silver" or fiat money could provide for the real needs of the people. ${ }^{34}$ Throughout 1893 and the election year of 1896, Flower ended his depictions of America gone wrong with the same endlessly reiterated panacea, like a litany: "reinstate silver or demonetize gold." 35 When the People's Party put forward this idea, they were mocked as "lunatics" but economist Milton Friedman later demonstrated that their financial policies were wiser than those of the "goldbugs" and fiat money has become a staple of $20^{\text {th }}$ century economic policies. ${ }^{36}$

\subsection{Populism as a moral crusade}

12 Middle-class Populist leaders, like Flower, could wrap calls for modernization in a preindustrial moral vision. As McMath put it, Populism combined "novel techniques with ancient values." ${ }^{37}$ Modernizing the economy and society aimed at destroying monopolies, thus instilling justice in the economic system. Reforms would shape an alternative future where all citizens would have a fair share of the benefits of modernity. For Flower, Populism was moral because it was modern and vice versa. The central role of women leaders in the crusade testified to both its modernity and moralism. Empowered women could educate reformers and purify politics, as shown by the work of female lecturers within Farmers' Alliances and the People's Parties as well as the articles, written by women, publicizing this work in The Arena. ${ }^{38}$ Economically speaking, demonetizing silver in 1873 had been a "moral crime" and speculating was as immoral as gambling. ${ }^{39}$ However, corruption was at its most serious when it came to concentration of capital and power. One in ten articles dealt with the abusive power of trusts which robbed the people of their fair share of American abundance (figure 4). The solution for Flower was cooperation, as it was both forward-looking and honest. Cooperatives represented a way to use scientific management techniques while defeating the concentration of capital and power in the hands of the "privileged few." It was the people's response to corporations: "it applie[d] to its work the economic principles of the trusts as they relate to organization, systematization, and administration, while keeping it on the high plane of brotherhood." 40

13 The Populist vision was anchored in an ethical vision resting on three pillars - a republican vision founded on producerism and democratic control, the Christian tradition of fairness, and the egalitarian sentiments of Jeffersonian democracy that opposed "special privilege." 41 Populism updated a moral vision that saw the United States as a commonwealth where individuals could - and should - compete on a level- 
playing field. Only immorality - corruption and greed - could account for the rejection of reforms. In Flower's moral reading of politics, Populists purposed to recapture the natural unity of people artificially divided by the schemes of corrupt corporations and designing politicians..$^{42}$ As a result, Flower called for the union of reformers regardless of parties, section, gender, race and line of work. However, this "natural" unity rested more on aspirations than facts. Workers and farmers never really joined forces and Tom Watson's appeal for a political alliance of poor Southern black and white farmers, much celebrated and widely circulated in pamphlet form, should not obscure the facts that Flower published only one article about Populism and "the Negro question" (figure 4) and that Watson eventually took part in the disenfranchisement of AfricanAmericans after the demise of Populism. ${ }^{43}$ For Flower, Populism "destroyed sectional prejudice" but its crusade for the moral regeneration of society rested on a restrictive definition of "the people" as white producers only ${ }^{44}$ For all his sympathy for the plight of the destitute immigrants he saw in Boston and his indignation at lynching, immigrants and minorities remained conspicuously absent from his prose. "The people's unity" also rested on exclusions. New geographical, social and moral divisions appeared in Populist rhetoric: the wealth-creating West vs. the speculating East, "the people" vs. plutocrats, producers and consumers vs. parasites..$^{45}$

\subsection{Populism and expertise}

14 For Populists, electoral politics should be purified by morally sanctified politicians but also by the disinterested knowledge of science. They did not resent expertise per se, as Hofstadter had it, but feared the monopoly on knowledge secured by experts working for plutocrats, as it would dispossess them of decision-making. ${ }^{46}$ Flower commended Arena experts as "authorities" to his readers: some overtly Populists like Congressman John Davis who wrote extensively about monetary policies; others with Populist sympathies, like Frank Parsons for the municipalization of public utilities, Thomas Will for municipal reform, and Carl Vrooman for the nationalization of railroads. ${ }^{47}$ Most of them had studied European experiments and travelled there, and used them to legitimize Populist measures. New Zealand was for them a model as it had implemented the kind of progressive policies Populists favored. Flower then publicized the reforms his contributors had culled from the transatlantic (and transpacific) reservoir of ideas. They also organized alternative educational institutions like the Populist-backed Kansas State Agricultural College (1897-1899), where Parsons, Will and Vrooman taught before Republicans dismissed them when they returned to power, and the Ruskin College in Trenton, Missouri, where Vrooman and Will taught after 1900. They intended to provide students with an alternative interpretation of the industrializing US and train future reformers. ${ }^{48}$

15 Thanks to alternative expertise, the people could resist "the college trust" that reorganized knowledge and fired professors who criticized corporations and laissezfaire orthodoxy. ${ }^{49}$ Populism feared and refused the nascent partnership between big business, universities and government that was to "engineer and manage a new America" in the $20^{\text {th }}$ century because it sanctioned the influence of corrupt, antidemocratic and exploitative private corporations in public life. ${ }^{50}$ Experts should provide people with reliable and unbiased knowledge; then "the people" could decide which policy to follow and, thanks to direct legislation, impose them on the country. For Flower, the initiative, the referendum and the recall were the only ways to 
maintain direct popular control over political decisions in a complex, enlarged industrial community.${ }^{51} \mathrm{He}$ attributed the success of direct democracy in the US after 1900 to the work of Populists..$^{52}$ Flower also dreaded the bureaucratization of expertise and its accompanying top-down social control and constraints on free inquiry. Experts were crucial for him to educate and agitate but he shied away from having them at the center of policy-making, what Progressives would do in the Wilson administration and later with the New Deal.

\subsection{Who owns history? Print culture and the legitimization of Populism}

Finally, Populists refused the corporate modernization narrative imposed by Republicans, Democrats, corporations and their experts - a monopoly on history for Flower. Populism had first and foremost a cultural role: reform print culture led to an "awakening of language" and revealed the "power of the people once awakened." ${ }^{3}$ This new "Great Awakening" illustrates the symbiosis between religion, politics, moralism, and literature within Populism. ${ }^{54}$ The circulation of progressive print culture was like the philosophers' pamphlets in Paris before the Revolution - it made the "revolt of the thinking toilers" possible. ${ }^{55}$ His historical model though was the agitation by the AntiCorn Law League in England in the 1840s as it showed how the alchemical transformation of the "mob" into "the people," through education and propaganda work, could lead to social change without any revolutionary bloodshed. ${ }^{56}$ Flower saw his journalistic work as the forum where a small band of reformers - Populists and others - could repeat English reform history.

Most contributions in Flower's magazines concentrated on the role of books. One in ten articles dealt exclusively with propaganda fiction and nonfiction and one fourth of Flower's editorials focused on literature (figure 4). Flower's Arena Publishing Company published essays, realistic novels, and utopian fiction, in other words works that enabled Populists to set the record straight about their actions. Flower especially promoted Hamlin Garland's realistic stories - Main-Travelled Roads, Jason Edwards and A Spoil of Office - that exposed the myth of Western prosperity, depicted the harsh realities of life in "the modern West" and refuted the image of Populists as "cranks." ${ }^{57} \mathrm{~A}$ Spoil of Office was the result of Garland's field study of the Kansas uprising financed by Flower; it was serialized in The Arena in 1892 and published afterwards in book form. ${ }^{58}$ Truthful accounts of Populist history in the making were complemented by optimistic utopian fiction: Brooklyn became a Populist cooperative paradise in Byron Brooks' Earth Revisited and a Martian's visit to a Populist utopia showed its female leaders as the epitome of modern management in John McCoy's A Prophetic Romance, Mars to Earth. ${ }^{59}$ Utopias served as a vehicle for the widespread desire to recapture a sense of historical agency over what politicians and plutocrats presented as an inevitable corporate order. They projected the realistic portrayal of Populism circulated in the reform press into the future: a historian made readers see the Populist alternative and demonstrated, by "looking backward," that this reform movement had been necessary. The future would prove Populism right because it followed the scientific laws of history. 


\section{What's the matter with B.O. Flower?: the fate of antimonopoly politics.}

\section{1 Paranoid style politics, Progressivism and conservatism}

18 Flower's own future took him to the rural Midwest. In 1916, he began to edit the antiCatholic Menace in Aurora, Missouri. In 1915, he had devoted all his time to writing a book with the telltale title: The Patriot's Manual, dealing with the irrepressible conflict between two mutually exclusive world theories of government; a compendium of facts, historical data, reasons and present-day chronicles, showing why every friend of fundamental democracy must oppose politico-ecclesiastical Romanism in its un-American campaign to make America "dominantly Catholic." ${ }^{00}$ His articles exemplified the same kind of "paranoid style," full of "heated exaggeration, suspiciousness and conspiratorial fantasy," that Hofstadter traced in populist discourse: 61

Two mighty influences [which] have, during the past fifty years, been steadily undermining our liberal democracy in the interest of monarchical and class-rule ideals of government: (1) The feudalism of privileged wealth, often called an invisible government of organized greed, and (2) the supreme and overshadowing menace of the monarchical and democracy-destroying upas-like Roman hierarchy, which is in effect a government within our Government, whose theory of rule is in direct opposition to vital and fundamental principles of our liberal democracy. ${ }^{62}$

Flower seems to have replaced financial conspiracy by Wall Street and English bankers with another type of conspiracy, which would tend to prove Hofstadter right since the logical conclusion of Flower's Populist discourse boils down to irrational resentments. However valid on the surface, this explanation is partial and reduces complex political and cultural evolutions to psychological explanations, that is to say in fine ahistorical question of character. Pathologizing Flower's political language, by pitting reason against irrational emotions, fails to account for his constant determination to ground his "moral enthusiasm" in scientific facts.

Flower was a progressive religiously speaking: he supported evolution, the separation of church and state, a version of Protestantism liberalized by the inputs of Unitarianism, Spiritualism and Christian science, and encouraged interreligious debates in his magazines. For Flower, anti-Catholicism was also a progressive crusade, like prohibition and "medical freedom," but urban liberals have since dismissed these causes as bigoted conservatism. ${ }^{63}$ Flower saw Catholicism as a "trust" and a corrupt "machine" and fighting against Romanism was merely the logical continuation of the fight against corporate power and political bosses. His Anglo-Saxonism was based on a racialist ideology which Hana Arendt has shown was a by-product of the modern imperial project, not the "survival of anachronistic racial attitudes" and "tribal parochialism" that supposedly plagued the "village mind." ${ }^{64}$ Fearing a Vatican plot and blaming World War One on the Pope are nonetheless typical examples of paranoid style politics with its conspiracy framed in apocalyptic terms, its moral absolutism, and its substitution of somebody's will for historical forces to account for social ills. This was also the fate of other Populists, like Tom Watson. ${ }^{65}$ How to make sense of such an evolution? Flower's story is also the story of Populism after its demise.

21 For Flower, Populism came to an end in 1896 when its party nominated Bryan on its presidential ticket and "merged into the Democratic organization." ${ }^{66} \mathrm{After} 1896$, his magazines featured only a few articles about Populism (figure 2). His comment about 
William Allen's article for the 1904 elections is typical: Populism was just a "timely topic;" the lyrical outbursts of the 1890s had disappeared. ${ }^{67}$ From 1900 onwards, Populism became the object of a retrospective, historical assessment and farmers were no longer presented as fearless progressives but, because of good crops and fair prices, as conservatives and victims, among many others, of trusts, as if they did not represent the radical spirit of antimonopolism anymore. For Flower, Ryan Walker's cartoon perfectly summed up the political situation (figure 5). ${ }^{68}$ The Arena focused less on farmers and slums and more on corporations and municipal reform - it was no longer the champion of a Populist solution to a Populist perception of problems.

Figure 5. Ryan Walker, "The Farmer and the Consumer and they who come between"

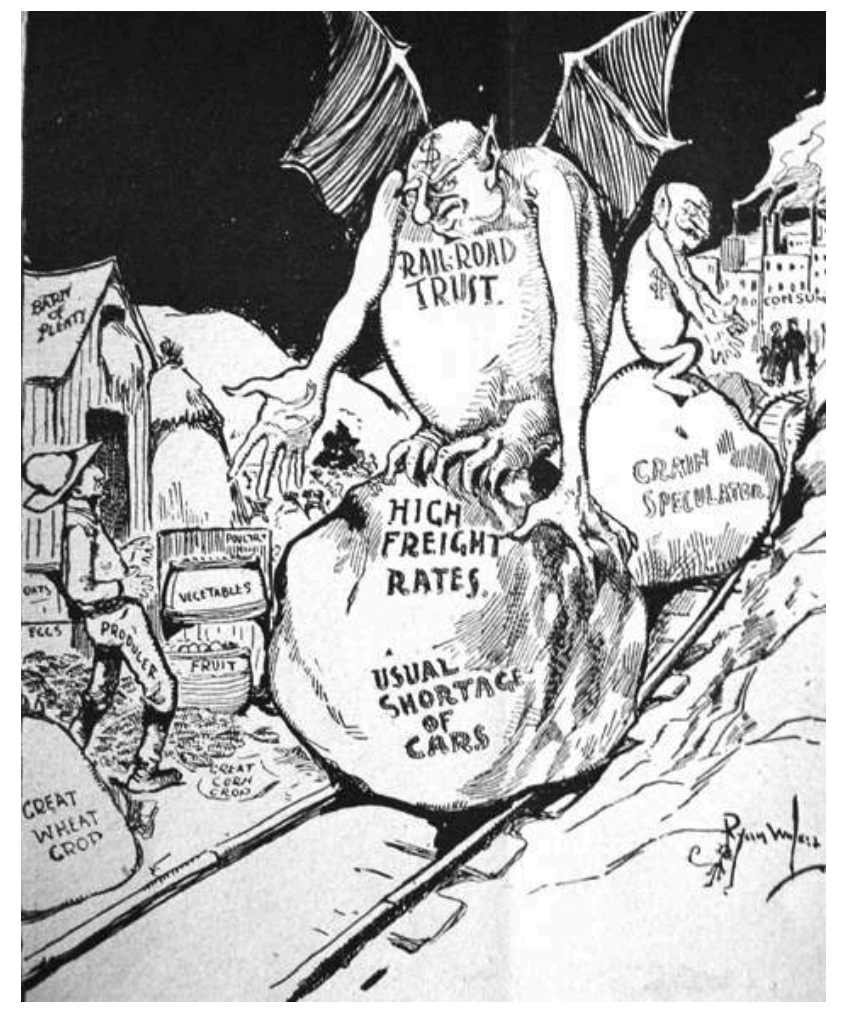

\subsection{The legacy of Populism: "voluntary socialism"}

Populist ideals therefore took refuge in what Flower approvingly called "progressive" or "voluntary socialism," not the German kind of "compulsory" or "military" socialism where the state, behaving like an all-powerful parent infantilizing children, displayed the same "favoritism" and despotic potential as in class legislation, but a home-grown version - the "Socialistic theory of justice and brotherhood" in the interest of individual freedom. For Flower, "modern socialism" would preclude any autocratic tendency because socialists were "fundamental democrats" - weren't they the first to favor direct legislation in their party platform ${ }^{69}$ The gradualist wing of Socialism was for Flower nothing more than the continuation of the Populists' - and in fine the antimonopolists' - political and cultural dissent carried on with other political means, thus blurring the boundary between the two movements. All the reforms he called "socialist" were the same as Populist reforms from the 1890s. The intellectuals he praised as Populist leaders in the 1890s, like Henry Demarest Lloyd, Frank Parsons, and 
Laurence Gronlund, came to represent socialist values; even Jefferson was put on the bandwagon. Many socialists were also former Populists - Eugene Debs, Ryan Walker, Julius Wayland, as well as the Vincent brothers. ${ }^{70}$ After 1896 , Flower contributed regularly to the Vincent brothers' Nebraska-based weekly, The American Nonconformist. ${ }^{71}$ Concurrently, he joined socialist publisher Charles Kerr in a new journalistic venture and co-edited the "semi-populist, semi-socialist magazine," The New Time (1897-1898). ${ }^{72}$ Most were based in or came from the Midwest (Texas and Missouri in particular), one of the Populist strongholds. Many Populists "voted red" because they felt betrayed by the merge with Democrats, especially when the conservative wing of the party recaptured power after Bryan's second failure in the 1900 presidential election. They saw in this "indigenous variation" of Socialism a political repository for their republican ideals and their moral fervor inherited from the prophetic tradition of American Protestantism. ${ }^{73}$ Socialism, after Populism, embodied agrarians "unschooled variant of the social gospel."74

This socialist detour is essential for two reasons: it reveals the link between homegrown Socialism and anti-Catholicism on the one hand and with antimonopoly Progressivism onthe other hand. First, these Populist-socialist Midwesterners seem to be linked to anti-Catholicism, as shown by the financial links as well as the common readership, subscription list and staff between Flower's paper The Menace and Wayland's socialist paper The Appeal to Reason based in Girard, Kansas. ${ }^{75}$ Jacob Sheppard epitomizes that link - he was an attorney for the United Mine Workers and other Socialist organizations in Kansas and also defended The Menace in January 1916 when its editors were called into Federal court in Joplin, MO, for trial on charges of using the mails to circulate obscene material. For Flower, Catholics were only trying to silence brave journalists who wanted to expose the turpitude of priests in particular and the corruption of a "political machine" in general. This was a question of freedom of speech for him. These attacks on journalism outraged him and were instrumental in his focusing exclusively on the "menace of Romanism." After the trial, he wrote the story of this "historic case" and cast this "mighty conflict" in eschatological terms - it was the latest episode in "the people's warfare throughout the ages in defense of their vital freedom from the assaults of despotic rulers, hierarchies and privilege-seeking classes." ${ }^{76}$ Secondly, the cultural division between the sophisticated New York type bohemian socialists and the culturally traditional and genteel Populist-socialists from rural areas overlapped with the cleavage between technocratic Socialists and antimonopoly Progressives, under its Populist or Socialist guise. In the 1910s, Flower's fight for "medical freedom" also laid bare the same division.

\subsection{The legacy of Populism: "medical freedom"}

24 At the beginning of the 1910s, Flower organized the National LeagueforMedical Freedom(NLMF). In October 1912, he was elected editor of Medical Freedom, the official journal of the League. ${ }^{77}$ As the president of the NLMF, he was fighting an all-out war against the "Owen Bill" that Senator Owen drafted in order to establish a Federal Department of Health and "adequate federal health regulation." 78 Many Progressives supported such a reform: the Republican, Democratic and Progressive parties in their respective health planks, labor unions, and the American Medical Association (AMA). ${ }^{79}$ They could not understand how Flower could oppose such a progressive measure. ${ }^{80}$ Technocratic Progressives applauded this move toward the centralization of several 
health bureaus into a more efficient Department of Health - science was used to improve society. They promoted the modernization and bureaucratization of health they wanted to manage, rationalize, and improve public health, notably by protecting consumers against the health dangers of patent medicines and the frauds of quacks.

Flower also framed his struggle in Progressive terms but used the language of antimonopoly. He saw in his fight against the Owen Bill and what he regarded as its behind-the-scene mastermind, the AMA, the crusade of unorganized patients and doctors, i.e. "the people," against organized "medical monopolies" - the AMA and the Federal state supported by corporations.$^{81} \mathrm{He}$ considered it as the struggle of alternative schools of medicine - homeopathy, osteopathy and Christian Science which represented intellectual liberty, the source of all progress, against the tyrannical will of "regular physicians" who wanted to impose their "medical dogmas" on the majority. Not only was he considering his fight for "medical freedom" as reformist - it was the last and crowning chapter in his memoir of the Progressive movement - but what was at stake was the definition of America as a free and advanced nation..$^{82}$ This so-called "progressive" health legislation was nothing more that the "fatal virus" of governmental favoritism extended to theprofessions with "law-bulwarked privilege" protecting "regular doctors." ${ }^{83}$ Flower fought against what he regarded as a "doctors' trust," thus transposing his Populist struggle for economic freedom and popular sovereignty into the sphere of intimacy and bodily integrity - what mattered was personal sovereignty, i.e. the right of patients to choose their treatments (figure 6).

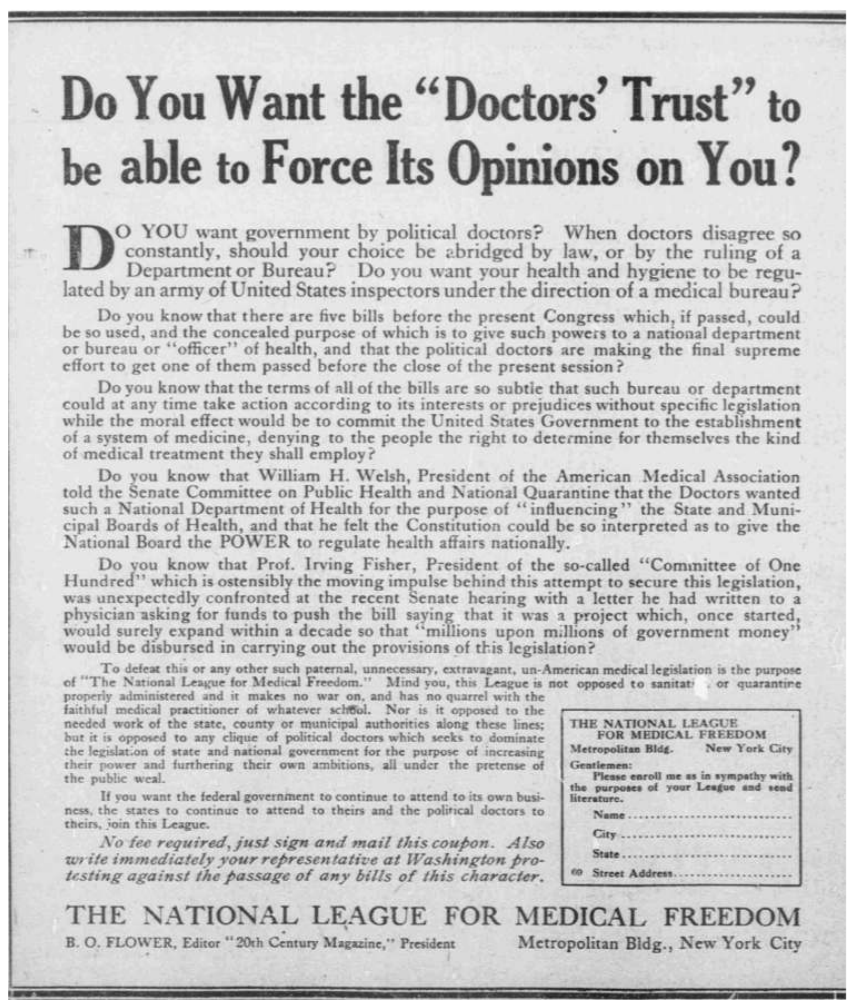

Flower also highlighted the epistemological conflict between antimonopoly Progressives and managerial liberals. Who had the legitimacy to determine which medical knowledge was valid in a science-oriented democratic society, or, as Flower put 
it, "who is to decide who the medical charlatans are?" ${ }^{44}$ The more technocratic strand of Progressivism believed in professionalized expertise, which, for Flower, meant "rob[bing] the people of the right and benefit of personally testing the virtue or truth of the newer systems or methods." ${ }^{85}$ The cultural split was between former Populists who thought experts should present facts to the people but citizens should decide what kind of medical treatment they wanted and those intellectuals disenchanted with ignorant masses who thought experts were more competent than the people and should decide for them. The Populist tradition therefore survived as a fight against the dispossession of decision-making by health experts and sophisticated intellectuals. Former Populists, for that matter, engaged in the fight: Sen. William Allen and James Weaver were both members of the NLMF. Journalists covering the story also noted that supporters of "medical freedom" came from Kansas City, Chicago and, in general, the West. ${ }^{86} \mathrm{That}$ the split within Progressivism happened at the beginning of the $20^{\text {th }}$ century and revolved around health issues makes sense, as it is with the regulation of private lives - with calls for prohibition and demands for consumer protection used for instance by Roosevelt to impose the Pure Food and Drug Act in 1906 - that managerial liberals did convince Americans to accept more government activism. Flower accepted government intervention to regulate the excesses of industrialization - i.e. economic and political ills - but refused any "special privilege" and infringement on personal sovereignty:

We are of those who would favor the state going far - very far - to remedy the wrongs that work injury to the weak and unfortunate, especially when the evils affect the young; but we unhesitatingly oppose the fastening on the body politic of representatives of a favored school of medicine. ${ }^{87}$

\subsection{Antimonopoly politics and anti-Catholicism}

In 1915, medical antimonopolists prevailed over managerial liberals. ${ }^{88}$ Flower retired as president of the NLMF in June - he was already busy writing his Patriot's Manual and, in November, became president of the Free Press Defense League (FPDL). The FPDL had been set up to conduct an "educational campaign" to awaken "the Protestant millions of America" and warn them of "the menace of Romanism." ${ }^{89}$ It also organized the defense of The Menace in preparation for the Joplin trial and helped all the "patriotic" Protestant publications that Catholics were allegedly trying to silence by using the Comstock laws. Using the same antimonopoly interpretative grid as in his crusade against the "doctors' trust," Flower fought against yet another un-democratic, dogmatic and hierarchical organization censoring citizens.

Flower's subsequent anti-Catholicism seems paradoxically due to the success of Populism. Plutocrats in 1915 were not yet defeated but, in the heyday of Progressivism, the battle was on - muckraking had awakened "the people," urban Progressives had "discovered the octopus," which had "stripped the radical veneer of Populism off the word 'People," and joined in the fight..$^{90}$ Flower thought he had reiterated the successful educational campaign waged by the Anti-Corn Law League - the recent acceptance of the Populist agenda by middle-class reformers had illustrated this "scientific law" of progress and the defeat of the "Owen Bill" seemed to be another case in point. ${ }^{91}$ Flower reprinted his account of the victory of the English reformers - it portrayed a peaceful method to "right the people's wrongs," except that in his 1917 preface, "Rome" replaced "plutocracy." ${ }^{2}$ History had always proved pioneers right and 
it would vindicate his anti-Catholic crusade. Flower's role, therefore, was to continue to be in the vanguard, suffer the scorn of skeptics who disparaged his exposure of the "Catholic machine" and "awaken" the sleeping consciences of "the people."

However, Flower now narrowed his understanding of "the people" to "the Protestant millions" and Americanized immigrants. Anglo-Saxonism, toned down before 1910 (even though "the people" had always implicitly been white producers) surfaced with a vengeance and blended with "ideological nativism," the idea that Catholicism was culturally incompatible with the genius of American democracy. ${ }^{93}$ The "Theory of Roman Hierarchy," as expressed by its history, traditions and Popes' proclamations, was "diametrically opposed to these three fundamental principles of our government" - freedom of speech and conscience, the absolute divorce of church and state and popular secular education. ${ }^{94}$ Like "prejudiced" believers in the Ptolemaic theory could not judge those who believed in the more advanced Copernican theory and like regular physicians who were incompetent to judge the cutting-edge methods of alternative medicine, Catholics, still steeped in old World "reactionary and autocratic theories of government," could not grasp the essence of America. ${ }^{95}$ Flower kept framing his crusades as epistemological conflicts and saw his detractors as unable to cope with a paradigm shift.

In the 1910s, the paradigmatic incommensurability between Romanism and the "Theory of our Fathers" (i.e. the Founding Fathers) was blended with Americanism, especially with the controversies over what Flower called "the Catholic war on public education." ${ }^{96}$ Catholics refused popular non-sectarian schools which, for Flower, were both the symbol and instrument of the "vast melting-pot of democracy." Flower applied his obsessive fear of governmental favoritism to his critique of Romanism - he objected to a paternalistic state assisting "150 different religions to wall off their children and teach them the dogmatic creeds which separate and antagonize, instead of bringing together the living units on one great body." The state/ church separation was a founding American principle, ergo Catholicism was "un-American." His list of immigrants, which, thanks to school, had been "fused into the free citizenship of the greatest democracy," illustrates restrictionist feelings prevalent at the time: it focused on "Slavs, Teutons, and Anglo-Saxons" and, apart from Greeks and Armenians, did not include Southern and Eastern immigrants. Ironically, when it came to fighting against Catholic dogmas and for state neutrality, free inquiry and social cohesion, Flower did become very dogmatic and divisive. ${ }^{97}$

31 Anglo-Saxonism and ideological nativism took on religious overtones. The ethically inclusive economic and social reforms of his Populist moment gave way to moral absolutism and an exclusive, militant campaign for a "New Reformation" - vox populi, vox dei became vox dei, vox populi. ${ }^{98} T$ The Menace crew took turn-of-the-century tensions between Catholics and Protestants to new heights and paved the way for the "culture wars" of the 1920s. One scholar even considered them as "begetters of the Klan." 99 Patriotism and Americanism at the core of the Populist vision - which, in fine, was meant to recapture the American promise defamed and corrupted by corporations drifted toward a religious understanding of Anglo-Saxonism and crystallized into a "self-conscious attempt 'to make a religion out of citizenship." 100 The line between loyalty to the genius of Protestantism, of the Anglo-Saxon race and of American democracy had become blurred - the terms of the civil religion had radicalized, so that any threat to Protestant traditions could be seen as "un-American." The issue was 
therefore essentialized: it was a question of national and religious identity, hence the increasing bitterness in Flower's discourse. The very character of the US was in peril and should be defended. ${ }^{101}$ Identity politics replaced interest politics because the acceptance of formerly ridiculed reforms, in particular the Populists' economic agenda, led Flower to focus on matters of personal belief. The "medical freedom" interlude reoriented his reformist energy from public matters - direct legislation, cooperation, railroad and currency reforms - to private issues. His antimonopoly understanding of America's wrongs, which had blended economic, social and cultural concerns before 1910, was therefore reduced to cultural divergences only. Under his pen, both medical monopolies and Catholic organizations were branded as "un-American." ${ }^{102}$ Prosperity probably also led him away from economic issues and World War One $100 \%$ Americanism probably functioned as a catalyst since it "stressed only the selfprotective, coercive aspects of the creed." ${ }^{103}$

\section{Conclusion}

Antimonopolist Populist-Progressives yearned "for a society run by and for ordinary people who lead virtuous lives." 104 Their economic radicalism was anchored in traditional lifestyles, most often Christian and conventional, and, for Progressives whose ideal was social cohesion based on scientifically-engineered modern techniques, the moral values of ordinary people were only expressing a dangerous kind of "populism," a relic from barbarous times. Even though Flower's intellectual, and even geographical, trajectory suggests a correlation between small-town America and "populism" (in its disparaging sense), we should not turn this connection into a causal relationship. Flower and Tom Watson did move from Populism to paranoid politics but the roads taken by Populists and nativists were many and contingent.

A technocratic understanding of society, whether in its corporate or governmental form, meant a change in scale, that is why small people feared the bureaucratic bigness and the reorganization of knowledge and power it implied. Debates were no longer political but epistemological (which knowledge was valid in a modern society) and legalistic (advancing facts and evidence to expose the invalidity of opponents' arguments). The common sense tradition had implied that citizens, expert or not, could see facts plainly, take decisions and come to an unbiased conclusion by sharing their perspectives. Power was now displaced from the democratic debate that involved all citizens, expert of not, to a technical debate between specialists. Antimonopolists therefore felt their way of life endangered not only by corrupt plutocrats but also by their well-meaning fellow Progressives who embraced managerial liberalism. The cultural condescension against Populism and the framing of "the people" as ignorant masses that started in the 1920 s corresponds to the demise of common sense as a cultural referent - managerial liberalism was to rule from then on.

Flower wanted to update common sense in order to maintain a link between small people and the bigness he felt was necessary and desirable for scientific management. With his propaganda for the People's Party, he wanted citizens to preserve a sense of ownership over politics, knowledge, history and the industrial economy. Populism for Flower seems then to function less as a political movement than as an interpretative grid, the avatar of antimonopoly politics that was available and usable at the beginning of the 1890s. With "medical freedom," it amounted to cultural resistance to the 
bureaucratization of medicine and the dispossession of decision-making it entailed that's to say policy matters. With anti-Catholicism, cultural resistance now dealt with matters of national identity, hence a more extreme form of dispossession and therefore a more extreme reaction. Contrary to Thomas Frank's analysis of the "Kansas problem," Flower's cultural concerns did not however trump his economic agenda - he just applied radical antimonopoly traditions to economic and cultural problems with a critique of private corporations, government bureaucracies and machine-like religious organizations. Flower explicitly saw them as three manifestations of tyrannical centralization; as an American, he could not but fight for freedom.

\section{NOTES}

1. In this paper, Progressive with a capital "P" will refer to the term used by historians for people and ideas related to the Progressive Era whereas "progressive" will simply mean favoring social reform and liberal ideas. Likewise, big "P" Populism will be used for the agrarian revolt of the 1890s and small "p" populism for the widely used but vaguely defined ideology and political discourse opposing "the people" and "the elites." Flower edited The Arena (1889-1909, with an interruption between 1896 and 1900), The New Time (1897-98), The Coming Age (1899-1900), The Twentieth Century Magazine (1909-11), Medical Freedom (1912-15) and The Menace (1916-17).

2. Robert H. Wiebe, The Search for Order, 1877-1920 (New York: Hill and Wang, 1967), 153. Wiebe uses the phrase for Thorstein Veblen. Frank Luther Mott, A History of American Magazines, Volume IV: 1885-1905, $1^{\text {st }}$ ed. (Belknap Press of Harvard University Press, 1957), 415. Hamlin Garland, A Son of the Middle Border (New York: Penguin Books, 1995), 329, 334-335.

3. Unless otherwise stated, magazine articles referenced in this paper are all extracted from The Arena.

4. Photographer unknown. Photo published before 1923 in the USA, public domain. Reprinted in 1932 in Cornelius C. Regier, The Era of the Muckrakers (Chapel Hill, NC: University of North Carolina Press, 1932): iv. Additional digital editing by Tim Davenport for Wikipedia, no copyright claimed. http://en.wikipedia.org/wiki/File:Flower-Benjamin-Orange.jpg, accessed 10 April 2013.

5. Flower, "Notes and Announcements," 5 (January 1892): 1.

6. William Allen White, "What's the matter with Kansas?" The Emporia Gazette, 15 August 1896.

7. Flower had "the reputation of a fighter for everything involving the spiritual, social and physical progress of humanity." It was therefore "inexplicable to many of his admirers how he could lead a movement opposed to the improvement of the health of the nation." Sigard Knopf, "The Owen Bill for the Establishment of a Federal Department of Health, and its Opponents," Popular Science Monthly 77 (October 1910): 376. For his years as editor of The Menace, see for example the incomprehension of historian Howard Cline and of Hamlin Garland, Flower's friend, who in his correspondence with Cline concurred with him: only poverty and senility could account for Flower's anti-Catholicism. Cline to Garland, 30 October 1938; Garland to Cline, 17 November 1938, container 125, Howard Francis Cline Papers, Manuscript Division, Library of Congress, Washington, D.C.

8. Walter Nugent, Progressivism: A Very Short Introduction, $1^{\text {st }}$ ed. (New York: Oxford University Press, 2009), 82. 
9. Thomas Frank, What's the Matter with Kansas? How Conservatives Won the Heart of America (New York: Henry Holt and Company, 2004); Larry M. Bartels, "What's the Matter with What's the Matter with Kansas?" Quarterly Journal of Political Science 1, n2 (26 April 2006): 1.

10. Flower, "W.J. Bryan, A Trustee of the People," 16 (September 1896): 695; Progressive Men, Women, and Movements of the Past Twenty-five Years (Boston: The New Arena, 1914), 96, 109.

11. Mott, A History of American Magazines, 407; Flower, Progressive Men, 99-100. For an example of subscription to The Arena, see Nebraska Farmers' Alliance Papers, 31 July 1894, New York Public Library, microfilm ZT-691, roll 1-998. Populist leaders advertised Flower's magazine: for instance, John W. Breidenthal, Chairman of the Kansas State Committee of the People's Party, encouraged party members to "subscribe for the ARENA, the greatest American review, the only review in the country that has given the reform movement fair treatment and friendly aid." Breidenthal, letter reproduced on the front end-paper of a book published by Flower (S.S. King, Bond Holders and Bread Winners: A Portrayal of Some Political Crimes Committed in the Name of Liberty), Item $\mathrm{n}^{\circ}$ 208059, Kansas Historical Society, Kansas Memory, www.kansasmemory.org/item/208059, accessed 17 March 2013. Farmers wrote congratulatory letters to Flower that he published in The Arena: "Notes and Announcements," 7 (January 1893): xxix.

12. Oxford English Dictionary. The Merriam-Webster dictionary traces the first use of the term to 1892 .

13. Willis Abbot, "The Chicago Populist campaign," 11 (February 1895): 336. Each of the 233 issues of The Arena had either 128 or 144 pages.

14. If a quantitative analysis of digitized texts is to be trusted - and we know such results should be treated with caution -, then Google Books Ngram Viewer seems to confirm the trend seen in the pages of The Arena. Comparison of "Populism" and "Populist" in American English between 1880 and 1940, http://books.google.com/ngrams/graph? content=Populism\%2CPopulist\&year_start=1880\&year_end=1940\&corpus=17\&smoothing=3\&share=, accessed 17 March 2013.

15. Flower, Progressive Men, 97; "Prospectus for 1894," 9 (December 1893): unnumbered page.

16. Online Etymology Dictionary, http://www.etymonline.com/index.php?term=populist, accessed 17 March 2013.

17. Henry Mencken, “What is Civilization?” The American Mercury 16 (January 1929): 123.

18. In 1915, the circulation of The Menace reached a high point of over 1.5 million. The links between Populism, Progressivism, Socialism and anti-Catholicism will be developed in part 3 . John Higham, Strangers in the Land: patterns of American nativism, 1860-1925 (New York: Atheneum, 1969): 184.

19. Michael Kazin, A Godly Hero: The Life of William Jennings Bryan, Reprint (New York: Anchor Books, 2007), 244.

20. Richard Hofstadter, The Age of Reform: from Bryan to F.D.R. (New York: Vintage Books, 1955); Anti-intellectualism in American Life (New York: Vintage Books, 1963); The Paranoid Style in American Politics, and other essays (New York: Vintage Books, 2008).

21. Kazin, A Godly Hero, 244.

22. See for instance: Walter Lippmann, Public Opinion (New York: Harcourt, Brace and Company, 1922) and Edward Bernays, Propaganda (New York: H. Liveright, 1928). Lippmann coined the phrase "manufacture of consent."

23. About the decline of small town America: Jean Kempf, "La petite ville: une nostalgie américaine," in Nostalgies américaines (Reims: Mallard, 2003), 94. About the culture wars of the 1920s: Hofstadter, The Age of Reform, 288-300.

24. Charles Postel, The Populist Vision (Oxford, New York: Oxford University Press, 2007), 19; Elizabeth Sanders, Roots of Reform: Farmers, Workers, and the American State, 1877-1917, $1^{\text {st }}$ ed. (Chicago, London: University of the Chicago Press, 1999), 16. 
25. Hofstadter, The Age of Reform, 62, 71-85; Anti-intellectualism, 37; David S. Brown, Richard Hofstadter: An Intellectual Biography (Chicago, London: University of Chicago Press, 2006), 112. Sanders, Roots of Reform, 2. The historiography of Populism is vast. A good starting point is Worth Robert Miller's synthesis: Worth Robert Miller, “A Centennial Historiography of American Populism," Kansas History: A Journal of the Central Plains 16 (Spring 1993): 54-69.

26. Flower, "The Menace of Plutocracy," 6 (September 1892): 508-516.

27. Flower, "Notes and Announcements. McDonald-Valesh," 5 (May 1892): li; Eva McDonaldValesh, "The Strength and Weakness of the People's Movement," 5 (May 1892): 726-731 and "The Tenement House Problem in New York," 7 (April 1893): 580-586.

28. Flower, Progressive Men, 98.

29. Flower, "Notes and Announcements," 5 (December 1891): xlvii.

30. Flower, Progressive Men, 100-102; J.R. Buchanan, "Revolutionary Measures and Neglected Crimes," 4 (June 1891): 93.

31. Christopher Lasch, The True and Only Heaven: Progress and its Critics (New York: W.W. Norton \& Company, 1991); Lawrence Goodwyn, The Populist Moment: A Short History of the Agrarian Revolt in America (Oxford, New York: Oxford University Press, 1978); Robert McMath, American Populism: A Social History, 1877-1898, $1^{\text {st }}$ ed. (new York: Hill and Wang, 1993) and "Another Look at the 'Hard Side' of Populism," Reviews of American History 36, $\mathrm{n}^{\circ} 2$, 2008: 209-217; James Livingston, Pragmatism, Feminism, and Democracy: Rethinking the Politics of American History (New York: Routledge, 2001) and Origins of the Federal Reserve System: Money, Class, and Corporate Capitalism, 1890-1913 (Ithaca, N.Y.: Cornell University Press, 1986); Postel, The Populist Vision, 270. The comparison of Populist historiography with tragedy and comedy is to be found in Postel.

32. Flower, "Pure Democracy vs. Vicious Governmental Favoritism," 8 (July 1893): 262.

33. Flower, "Books of the Day. Esau, or the Banker's Victim by T.A. Bland," 6 (August 1892): xliii.

34. Flower, "Pure Democracy," 270. The circulation of silver literature in The Arena, especially between 1892 and 1896, no doubt prepared the reception of Bryan's "Cross of Gold Speech" at the Democratic National Convention in 1896 (figure 2).

35. Flower, "Notes and Announcements. The Present Peril," 8 (August 1893): xx; "Notes and Announcements. Two Typical Cases of Life's Tragedies," 8 (September 1893): xxxiii.

36. Flower, "Pure Democracy," 271. Milton Friedman, "Bimetallism Revisited," The Journal of Economic Perspectives 4 (1 October 1990): 85-104 and "The Crime of 1873," Journal of Political Economy 98 (December 1990): 1159-1194.

37. McMath, "Another Look at the 'Hard Side' of Populism," 216.

38. Flower, Progressive Men, 98-99. Flower, "McDonald-Valesh," li; Annie L. Diggs, "The Farmers' Alliance and Some of its Leaders," 5 (April 1892): 590-608; "The Women in the Alliance Movement," 6 (July 1892): 160-180; McDonald-Valesh, "The Strength and Weakness of the People's Movement," 726-731 and "The Tenement House problem in New York," 580-586.

39. Flower, "Notes and Announcements. The President of a Leading New York Bank on Silver," 8 (September 1893): xxx; “Pure Democracy," 266-269.

40. Flower, "The Struggle between Life and Death in the Economic World. The Warfare of Three World-wide Social Theories," 27 (March 1902): 321.

41. Flower, "Pure Democracy," 263-272; Michael Kazin, The Populist Persuasion: An American History, rev. ed. (Ithaca, N.Y.: Cornell University Press, 1998), 13; Lasch, The True and Only Heaven, 223; McMath, "Another look at the 'Hard Side' of Populism," 216; Nugent, Progressivism, 24.

42. Flower, "The Menace of Plutocracy," 511.

43. Thomas E. Watson, "The Negro question in the South," 6 (October 1892): 540-550; Comer Vann Woodward, Tom Watson: Agrarian Rebel (Oxford University Press, 1979), 370-386.

44. Flower, Progressive Men, 102.

45. Flower, "The Present," 1 (January 1890): 241; "Social Conditions Under Louis XV. A Lesson for the Present Day," 4 (October 1891): 637; "Books of the day. Darkness and Daylight; or, Lights and 
Shadows in NY by H. Campbell," 6 (July 1892): xli; "Four Epochs in the History of our Republic," 16 (November 1896): 928-936.

46. Hofstadter, Anti-intellectualism, 34.

47. John Davis, "The Money Question," 5 (April 1892): 543-555; "The Communism of Capital - the Real Issue Before the People," 6 (September 1892): 417-419; "Honest and Dishonest Money," 9 (February 1894): 359-369.

Parsons wrote 25 articles about exemplary social and economic policies in New Zealand and Great Britain; see for example: "The People's Highways. part I and II," 12 (April and May 1895); "The Telegraph Monopoly. From part I to part X," vol. 15, 16 and 17 (from January to December 1896).

In 1913, Carl Vrooman became the Senator from Illinois and then Assistant Secretary of Agriculture for President Wilson. Flower, Progressive Men, 117-118; Vrooman, "Railway Nationalization in France," 40 (August-September 1908): 156-163; “Our Railroad Riddle," 40 (December 1908): 553-560.

48. Flower, Progressive Men, 118, 129; "An Economist with Twentieth Century Ideals," 26 (August 1901): 166-168.

49. Thomas E. Will, "A Menace to Freedom: The College Trust," 26 (September 1910): 244-257.

50. Olivier Zunz, Why the American Century?, New ed. (Chicago: University of Chicago Press, 2000): xi.

51. As Goodwyn puts it: "Populist theory poses the central twentieth-century political question: can large government be democratic?" (The Populist Moment, 319). Flower wrote extensively about the benefits of direct democracy: Progressive Men, 61-70; "The Difference Between a real and a Pseudo Republic," 29 (April 1903): 421; "Democracy and Municipal Government; or, How the Richest Town in the World is Ruled by the Referendum," 32 (October 1904): 380; "Authoritative Statements as to the Practical Working of Direct-Legislation in Switzerland and American," 38 (August 1907): 322.

52. Flower, "In the Mirror of the Present. Direct Legislation in Oregon and the Misrepresentations of the Reactionary Press," 38 (July 1907): 82.

53. Alan Trachtenberg, The Incorporation of America: Culture and Society in the Gilded Age, $1^{\text {st }}$ ed. (New York: Hill and Wang, 1982), 178; Flower, Progressive Men, 101; “The Arena for 1892," xliii.

54. Interestingly, in most utopias published by Flower, time travellers are literally mesmerized into a regenerated America - "awakening," whether intellectual, spiritual or literal - was tantamount to reform.

55. Flower, "Pure Democracy," 260; “The Broadening Horizon of Civilization," 5 (May 1892): 779.

56. Flower, "How England Averted a Revolution of Force," 24 (October 1900); 358-378; How England Averted a Revolution of Force; A Survey of the Social Agitation of the First Ten Years of Queen Victoria's Reign (Trenton, N.J.: A. Brandt, 1903); Progressive Men, 102, 151.

57. Hamlin Garland, Main-Travelled Roads: Six Mississippi Valley Stories (Boston: The Arena Publishing Company, 1891); Jason Edwards: An Average Man (Boston: The Arena Publishing Company, 1892); A Spoil of Office: A Story of the Modern West (Boston: The Arena Publishing Company, 1892).

58. Flower, "Notes and Announcements. A Spoil of Office," 5 (January 1892): xlviii; Garland, A Son of the Middle Border, 228-339.

59. Byron Alden Brooks, Earth Revisited (Boston: The Arena Publishing Company, 1894); John McCoy, A Prophetic Romance, mars to Earth (Boston: The Arena Publishing Company, 1894).

60. Letter from Flower to Theodore Schroeder, 9 November 1915, Box 24, Series 1: Correspondence, Theodore Schroeder papers, Special Collections Research Center, Southern Illinois University Carbondale. Flower, The Patriot's Manual (Fort Scott, Kan.: Free Press Defense League, 1915)

61. Hofstadter, The Paranoid Style in American Politics, 3. 
62. Flower, Righting the People's Wrongs; A Lesson from History of Our Own Times (Cincinnati: The Standard Publishing Company, 1917), 5.

63. Lasch, The Agony of the American Left (New York: Vintage Books, 1969), 13.

64. Lasch, The True and Only Heaven, 445-446.

65. Woodward, Tom Watson, 416-430.

66. Flower, Progressive Men, 102.

67. Flower, "Hon. William V. Allen on the People's Party," 30 (October 1903): 447; "Mirror of the Times. The People's Party," 32 (September 1904): 314-315.

68. Flower, "One Reason Why the Farmers are Poor; or, the Armour Car Company Responsible for the Waste of Hundreds of Thousands of Dollars' Worth of Fruit," 34 (October 1905): 426-429.

69. Flower, "Pure Democracy," 260-268; "A Brief Survey of Social Progress in the English Speaking World," The New Time 2 (May 1898): 309-312.

70. Flower, Progressive Men, 90, 99; “A Brief Survey of Social Progress,” 309-312.

71. Harold Piehler, "Henry Vincent: Kansas Populist and radical-reform Journalist," Kansas History 2 (spring 1979): 14-25. "Advert for The American Nonconformist," Howard Francis Cline Papers.

72. Allen Ruff, "We called each other comrade": Charles H. Kerr \& Company, Radical Publishers (Urbana: University of Illinois Press, 1997), 77-81.

73. Flower, "Union of Socialistic Forces," 26 (October 1900): 430-431; Garin Burbank, When Farmers Voted Red: The Gospel of Socialism in the Oklahoma Countryside, 1910-1924, Contributions in American History; no53 (Westport, Conn.: Greenwood Press, 1976), 14; Elliott Shore, Talkin' Socialism: J.A. Wayland and the Radical Press (Lawrence, Kan.: University Press of Kansas, 1988).

74. Burbank, When Farmers Voted Red, 15.

75. Shore, Talkin' Socialism, 193-194, 222; Burbank, When Farmers Voted Red, 29-30; George Milburn, "The Menace," The American Mercury 25 (March 1932): 324-327; John F. Noll, "Topics of Interest: Data on Anti-Catholicism," America: A Catholic Review of the Week 15 (July 29, 1916): 369. Noll was a Catholic bishop and the editor of Our Sunday Visitor, a weekly newspaper founded in 1912 to respond to The Menace. Another telling example is the numerous letters sent by reformist Midwesterners to Bryan in 1908 that blamed his defeat on a Catholic plot or Debs' ambiguous relationship with Catholics. Kazin, A Godly Hero, 165-168; J. Robert Constantine and Eugene V. Debs, Gentle Rebel: Letters of Eugene V. Debs (Urbana: University of Illinois Press, 1995), 93-94. Fred Warren, the editor of The Appeal to Reason during the 1910s, did not support attacks on Catholics and denied any business and ideological connection with The Menace. Fred D. Warren, "Ownership of The Menace," The Appeal to Reason, 28 December 1912, 3; "Facts about The Appeal," The Appeal to Reason, 5 July 1913, 1.

76. Flower, Story of the Menace Trial: A Brief Sketch of this Historic Case With Reports of the Masterly Addresses by Hon. J.L. McNatt and Hon. J.I. Sheppard, Attorneys for the Defense (Aurora, Mo.: United States Publishing Co., 1916), unnumbered page; Reuben Maury, The Wars of the Godly (New York: Robert M. McBride \& Company, 1928), 262-264; "Obituary, J.I. Sheppard Dies, Prominent Kansas Dies at Fort Scott," Topeka Journal, 19 October 1921; Gilbert O. Nations, "Benjamin Orange Flower," The Menace, 4 January 1919, 1.

77. Medical Freedom 2 (October 1912): 2.

78. "Medical Economics. Newspaper Comments of the Public Health Campaign," Journal of the American Medical Association 56 (20) (May 18, 1912): 1528. For a chronological narrative of the controversy, see Stephen Petrina, "Medical Liberty: Drugless Healers Confront Allopathic Doctors, 1910-1931," Journal of Medical Humanities 29, ํㅜ (August 7, 2008): 205-230.

79. Irving Fisher, "National Health and Medical Freedom. Both Sides of a Question of Public Interest," Century Magazine 85 (February 1913): 514; Knopf, "The Owen Bill,” 374, 376.

80. Irving Fisher, "Defines Opposition to the Owen Bill," The New York Times, June 18, 1910. 
81. Hofstadter defined Progressivism as "the complaint of the unorganized against the consequences of organization." The Age of Reform, 216.

82. Flower, Progressive Men, 298-316.

83. Flower, "Pure Democracy," 268-269; Progressive Men, 298, 300.

84. Flower, "National Health and Medical Freedom. Both Sides of a Question of Public Interest," Century Magazine 85 (February 1913): 512.

85. Flower, Progressive Men, 300.

86. “Beware, O Ye Doctors!" New-York Tribune, 16 May 1910, 12.

87. Flower, "The Compulsory Medical Inspection of School Children," The Twentieth Century Magazine 4 (May 1911): 160.

88. A heated debate raged until 1916, when the final attempt to pass the Owen bill was defeated and the League finally disbanded. "The Closing of the League," Medical Freedom 6 (September 1916): 2.

89. "Annual Meeting of the League," Medical Freedom 4 (June 1915): 148; "The Free Press Defense League," The Menace, 6 November 1915, 3 and 13 November 1915, 4; "The Conscience Element of America and The Menace," The Menace, 12 February 1916, 1.

90. The phrase was uttered in 1905 by William Allen White, the Progressive editor who had excoriated the Populists in 1896. Daniel T. Rodgers, "In Search of Progressivism," Reviews in American History 10, $\mathrm{n}^{\circ} 4$ (December 1, 1982): 124 and Contested Truths: Keywords in American Politics since Independence (Cambridge, Ma.: Harvard University Press, 1998), 183.

91. Flower, How England Averted a Revolution of Force; ProgressiveMen, 102, 151.

92. Flower, Righting the People's Wrongs, 3, 6, 13.

93. Justin Nordstrom, Danger on the Doorstep: Anti-Catholicism and American Print Culture in the Progressive Era (Notre Dame, Ind.: University of Notre Dame Press, 2006), 29.

94. Flower, "Why Rome Wars on the Public Schools," The Menace, 18 December 1915, 4.

95. Ibid., 4; Flower, "Christian Science and Organic Disease," 38 (November 1908): 443-444.

96. Flower, "Why Rome Wars on the Public Schools," 4.

97. Ibid., 4; Flower, Righting the People's Wrongs, 4.

98. Ibid., 10 .

99. Maury, The Wars of the Godly, 247-270; Milburn, “The Menace," 330-331.

100. Michael Walzer quoted in Michael Kazin, Rebecca Edwards, and Adam Rothman, eds., The Concise Princeton Encyclopedia of American Political History (Princeton University Press, 2011), 12-13.

101. Joseph Anthony McCartin and Michael Kazin, Americanism: New Perspectives on the History of an Ideal (Chapel Hill: University of North Carolina Press, 2006), 5. Things became extremely violent in the end: The Menace plant was dynamited on 29 July 1916. It finally burnt down on 11 December 1919. By that time, Americans had grown weary of anti-Catholic propaganda and circulation of the newspaper fell from the wartime peak. However, Flower, who had been suffering from diabetes since 1917, "did not care; he was on his way to die in Boston." "Plant of the Menace Damaged by Bombs," The New York Times, 30 July 1916; Frank Peters, "Few who saw it will ever forget restless, glowering - The Menace," Springfield, Mo. News-Leader, February 21, 1960; Milburn, "The Menace," 328; Howard Francis Cline, The Mechanics of Dissent: Benjamin Orange Flower and his Arena, the story of a man and his magazine (senior honors thesis, Harvard, 1939), Harvard University Archives; "Menace Publishing Company Burned with \$125,000 Loss," Dallas Morning News, 12 December 1919.

102. The aim of the NLMF was "the maintenance of the rights of the American people against unnecessary, unjust, oppressive, paternal and un-American laws, ostensibly related to the subject of health." Medical Freedom 1 (September 1911): 2. Flower denounced the "un-American Campaign to Make America 'Dominantly Catholic"' (according to his Patriot's Manual).

103. Kazin, The Concise Princeton Encyclopedia of American Political History, 14.

104. Kazin, A Godly Hero, 306. 


\section{ABSTRACTS}

This article proposes a reconstructive understanding of Populism from the perspective of Boston reform editor Benjamin 0 . Flower, one of its main publicists. It purposes both to recapture the meaning of "Populism" as it was understood in the 1890s and to trace its fate at the beginning of the $20^{\text {th }}$ century - the ambiguous evolution of Flower, from champion of radical reforms to antiCatholic crusader at the end of his life, will be used as a case study to examine how and why Populism might overlap with paranoid-style politics. This paper argues that such intellectual trajectories as Flower's should not be dismissed as the expression of populist psychopathology but can be best understood as the byproduct of ideological conflicts within Progressivism. Populism could then be considered as just one moment in the confrontation between the more radical antimonopoly strand of Progressivism and the managerial liberalism fostered by the more technocratic elements among Progressives.

\section{INDEX}

Keywords: Benjamin Orange Flower, The Arena, The Menace, National League for Medical Freedom, Free Press Defense League, Populism, antimonopoly, paranoid style, Progressivism, voluntary socialism, medical freedom, anti-Catholicism, experts, modernity/ tradition, rural/ urban, moralism, print culture, reform press

\section{AUTHOR}

JEAN-LOUIS MARIN-LAMELLET

Jean-Louis.Marin-Lamellet@univ-lyon2.fr 